http:/www.journals.zu.edu.eg/journalDisplay.aspx?Journalld=1\&queryType=Master

\title{
CHEMICAL COMPOSITION AND THE ANTIOXIDANT ACTIVITY OF TWO EDIBLE MUSHROOMS
}

\author{
Amaal S. Mohammed", A.O. Osman, R.A. El Masry and S.S. El Saadany \\ Agric. Bioch. Dept., Fac. Agric., Zagazig Univ., Egypt
}

\section{Received: 18 /3/2018 ; Accepted: 02/05/2018}

\begin{abstract}
The proximate composition and minerals contents of two edible mushroom (Pleurotus ostreatus and Agaricus bisporus) flours used in Egypt were investigated. Also, ethyl acetate, ethanol, methanol and distilled water were used to fractionate soluble compounds from the mushrooms in ascending polarity by sequentially extracting. As well as, total phenolic, total flavonoid compounds and the antioxidants activity for these extracts were investigated. The percentage moisture content ranged between $90.47 \%$ in Pleurotus ostreatus to $90.55 \%$ in Agaricus bisporus. The crude protein ranged from $3.25 \%$ in Pleurotus ostreatus to $3.48 \%$ in Agaricus bisporus. Total carbohydrates ranged from 5.23\% in Agaricus bisporus to $5.35 \% \pm 0.03$ in Pleurotus ostreatus. The most abundant mineral element is potassium (ranging from 2376.8 to $2820.5 \mathrm{mg} / 100 \mathrm{~g}$ on dry weight base (DW) for Agaricus bisporus and Pleurotus ostreatus, respectively) followed by Phosphorus (ranging from 537 to $754 \mathrm{mg} / 100 \mathrm{~g}$ on DW for Pleurotus ostreatus and Agaricus bisporus, respectively). The antioxidant activity of different extracts for two mushrooms (Agaricus bisporus and Pleurotus ostreatus) increased gradually as concentration increases. These results compatible with those results recorded for total phenolic compounds of investigated mushroom. In conclusion, mushrooms, in spite of the great variability observed among species, represent an interesting food item that can contribute to the formulation of a well-balanced diet.
\end{abstract}

Key words: Agaricus bisporus, Pleurotus ostreatus, proximate analysis, minerals, total phenolic compounds, antioxidant activity.

\section{INTRODUCTION}

Edible mushrooms are valuable healthy foods, having rich source of vitamins, proteins and minerals, especially in potassium and phosphorus. They are also low in calories and fats (León-Guzmán et al., 1997; Öztürk et al., 2011). Oyster mushrooms (Pleurotus ostreatus) and champignons (Agaricus bisporus) are regularly used as raw ingredients in the preparation of various dishes, as well as food stocks, replacing chicken stocks. Champignons are commercially available in three varieties, white, brown and Portobello.

In recent years, amounts of used mushrooms have risen greatly, involving a large number of species, due to continuous developments in cultivation, harvest, postharvest, processing and storage treatments, which facilitates the consumption throughout the year. Along the nutritional properties (Barros et al., 2007). Mushrooms have been demonstrated to possess healthy properties (Lindequist $\boldsymbol{e t}$ al., 2005) and they have evidence to be efficient as antiinflammatory, antitumor, antibacterial, antioxidant and antiviral agents (Dore $\boldsymbol{e t}$ al., 2007; Chen $\boldsymbol{e t}$ al., 2009; Garcia-Lafuentea et al., 2010). Recently, they have become increasingly attractive as functional foods due to their potential beneficial effects on human health. Hence, food industry is especially interested in both cultivated and wild edible mushrooms. The most extensively cultivated mushroom worldwide are Agaricus bisporus and Pleurotus ostreatus. Among the biologically active articles

Corresponding author: Tel. : +0201210162653

E-mail address: amaal33ali@gmail.com 
present in mushrooms, phenolic compounds have attracted much awareness due to their excellent properties as antioxidant, antiinflammatory or anti-tumour articles, among others (Puttaraju et al., 2006).

In the present work, two edible mushrooms collected from Egypt (Pleurotus ostreatus and Agaricus bisporus) were studied for detailed chemical composition. Also, ethyl acetate, ethanol, methanol and distilled water were used to fractionate soluble compounds from the mushrooms in ascending polarity by sequentially extracting. As well as, total phenolic, total flavonoid compounds and the antioxidants activity for these extracts were investigated.

\section{MATERIALS AND METHODS}

\section{Mushroom}

Oyster mushroom (Pleurotus ostreatus) was purchased from Horticulture Department, Faculty of Agriculture, Zagazig University, Egypt. Champignons (Agaricus bisporus) was purchased from local market, Zagazig city, Egypt.

\section{Chemical Composition}

\section{Proximate analyses}

Proximate analysis of the mushrooms, including moisture, ash, crude protein, crude fat and total carbohydrates were determined in triplicate, according to (Horwitz and Latimer, 2000). The moisture content was determined by further heating of the dried sample at $105^{\circ} \mathrm{C}$ overnight until constant weight; the ash content was determined by weighing the incinerated residue obtained at $550^{\circ} \mathrm{C}$ for $24 \mathrm{hr}$., the crude protein content $(\mathrm{N} \times 4.38)$ was determined by the Kjeldahl method (Braaksma and Schaap, 1996; Okoro and Achuba, 2012) the crude fat content was determined by Soxhlet extraction with petroleum ether as a solvent (Fernandes $\boldsymbol{e t}$ al., 2014). Total carbohydrate content was determined by measuring the absorbance of phenol and concentrated sulfuric acid extracts at 490 nm (Dubois et al., 1956).

\section{Mineral analysis}

The mushroom sample ( $1 \mathrm{~g})$ was placed in a porcelain crucible and ashed in a muffle furnace at $500^{\circ} \mathrm{C}$ for $24 \mathrm{hr}$. After cooling, the ashed material was dissolved in $2 \mathrm{ml}$ of concentrated $\mathrm{HNO}_{3}$, and diluted with distilled water up to 25 $\mathrm{ml}$. The solution was then transferred to a suitable container, after it was filtered through filter paper. A blank digest was carried out in the same way. The concentrations of iron $(\mathrm{Fe})$, zinc $(\mathrm{Zn})$, potassium $(\mathrm{K})$, sodium $(\mathrm{Na})$, calcium $(\mathrm{Ca})$, manganese $(\mathrm{Mn})$, copper $(\mathrm{Cu})$, and magnesium $(\mathrm{Mg})$ were determined by a graphite furnace atomic absorption spectrometry (Thermoscientific/Germany). Phosphorus (P) was determined by molybdenum blue spectrophotometry (UV-160A Shimadzu/Japan) according to (Adejumo and Awosanya, 2005).

\section{Preparation of Extracts}

The mushroom samples (Pleurotus ostreatus and Agaricus bisporus) were cleaned manually, cut and lyophilized (Thermo-electron Corporation - Heto power dry LL 300 Freeze dryer). Then, the lyophilized powder was defatted using nhexane. Ethyl acetate, ethanol, methanol and distilled water to fractionate soluble compounds from the mushrooms in ascending polarity by sequentially extracting (Smolskaitė et al., 2015). Twenty grams ground mushrooms were extracted with different solvents $(200 \mathrm{ml})$ using magnetic stirrer at room temperature for $2 \mathrm{hr}$., followed by filtration through Whatman No.1 filter paper. The residues were re-extracted under the same conditions. The samples were air dried after each solvent extraction and finally the residues were extracted with boiling water during $2 \mathrm{hr}$. Organic solvents were removed in a vacuum rotary evaporator (BüCHI-water bathB-480), while water extracts were freeze-dried (Thermo- electron Corporation-Heto power dry LL 300 Freeze dryer). All extracts were kept in a refrigerator until further analysis.

\section{Total Phenolic Compounds (TPCs) Determination}

The TPCs were measured with Foline-Ciocalteu reagent as described by (Singleton $\boldsymbol{e t}$ al., 1999). One $\mathrm{ml}$ of sample $(1000 \mu \mathrm{g}$ in $1 \mathrm{ml})$ was mixed with Folin-Ciocalteu reagent $(5 \mathrm{ml}$, previously diluted with water $1: 10, V / V)$ and sodium carbonate $(75 \mathrm{~g} / \mathrm{l}, 4 \mathrm{ml})$. The tubes were vortex mixed for $15 \mathrm{~s}$ and allowed to stand for $30 \mathrm{~min}$ at $40^{\circ} \mathrm{C}$ for colour development. Absorbance 
was then measured at $765 \mathrm{~nm}$. Gallic acid was used to obtain the standard curve $(20-200 \mu \mathrm{g} /$ $\mathrm{ml}$ ), and the reduction of Folin-Ciocalteu reagent by the samples was expressed as mg of gallic acid equivalents (GAE) per $g$ of extract. The calibration equation for gallic acid was $\mathrm{y}=$ $0.001 \mathrm{x}+0.0563\left(\mathrm{R}^{2}=0.9792\right)$, where $\mathrm{y}$ is absorbance and $\mathrm{x}$ is concentration of gallic acid in $\mu \mathrm{g} / \mathrm{ml}$ (Fig. 1).

\section{Total Flavonoids (TFs) Determination}

Total flavonoids (TFs) were measured according to the method of (Ordonez et al., 2006) with some modification. Two $\mathrm{ml}$ aliquot of $20 \mathrm{~g} / \mathrm{l} \mathrm{AlCl}{ }_{3}$ ethanol solution was added to 1 $\mathrm{ml}$ of the extract (1000 $\mu \mathrm{g}$ in $1 \mathrm{ml}$ solvent). After $60 \mathrm{~min}$, the absorbance at $420 \mathrm{~nm}$ was recorded. Quercetin was used to obtain the standard curve (20-200 $\mu \mathrm{g} / \mathrm{ml})$, Total flavonoids contents expressed as quercetin equivalent $(\mathrm{QE})$, which was calculated based on the calibration curve (Fig. 2).

\section{Antioxidant Activity Evaluation (DPPH- assay)}

The electron donation ability of each extract was recorded by bleaching of the DPPH purple colored solution according to (Hatano et al., 1988). Five hundred $\mu$ l of each extract at different concentrations $(100,250,500,1000$, 1500 and $2000 \mu \mathrm{g}$ extract $/ 1 \mathrm{ml}$ solvent) were added to $2.5 \mathrm{ml}$ of $0.1 \mathrm{mM}$ DPPH dissolved in ethyl acetate or ethanol or methanol according to the solvent used for extraction. After incubation time of $30 \mathrm{~min}$ at room temperature, the absorbance was recorded against the control at $517 \mathrm{~nm}$ (Gülçin et al., 2004). Percentage of antioxidant potential of DPPH radicals was calculated as follow:

\section{Inhibition $(\%)=[(\mathrm{Abs}$ control-Abs sample)/Abs control] $\times 100$}

Where Abs. control is the absorbance of the control and Abs. sample is the absorbance in the presence of mushroom extract.

\section{RESULTS AND DISCUSSION}

\section{Proximate Composition}

Proximate analyses were carried out on two edible mushroom species: Pleurotus ostreatus and Agaricus bisporus. They were selected based on their availability. Results of proximate composition are presented in Table 1.

The percentage of moisture content ranged between $90.47 \% \pm 0.88$ in Pleurotus ostreatus to $90.55 \% \pm 0.65$ in Agaricus bisporus. The ash content ranged from $0.43 \% \pm 0.004$ in Agaricus bisporus to $0.65 \% \pm 0.002$ in Pleurotus ostreatus. The crude fat ranged from $0.22 \%$ \pm 0.002 in Agaricus bisporus to $0.28 \% \pm 0.003$ in Pleurotus ostreatus. The crude protein ranged from $3.25 \% \pm 0.02$ in in Pleurotus ostreatus to $3.48 \% \pm 0.01$ in Agaricus bisporus. Total carbohydrates ranged from $5.23 \% \pm 0.02$ in Agaricus bisporus to $5.35 \% \pm 0.03$ in Pleurotus ostreatus. Dry matter content of fresh mushrooms is relatively low, i.e. around $10 \%$, and is mainly composed of carbohydrates, proteins, fibre and minerals (Wang et al., 2014). When considering the chemical composition of mushrooms, it is worthwhile to keep in mind that water content is the parameter that is to some degree, variable for fresh mushroom. This is because changing weather conditions can to some degree influence the moisture content of collected fruiting bodies (mushrooms). Fruiting bodies, after collection, also lose moisture easily due to evaporation. There is a consensus that the moisture content of fresh fruiting bodies is $90 \%$ (Chudzyński and Falandysz, 2008). The proximate composition of mushrooms also varies within and among species, and fruiting body maturity can also play a role. As well as, the environmental factors can have an impact on the abundance of certain compounds in mushrooms.

\section{Mineral Analysis}

Table 2 show the mineral contents of the samples analysed. The mineral constituents, are in agreement with other literature data (Manzi et al., 1999; Manzi et al., 2004), the most abundant mineral element is potassium (ranging from 2376.8 to $2820.5 \mathrm{mg} / 100 \mathrm{~g}$ on dry weight base for Agaricus bisporus and Pleurotus ostreatus, respectively) followed by Phosphorus (ranging from 537 to $754 \mathrm{mg} / 100 \mathrm{~g}$ on dry weight base for Pleurotus ostreatus and Agaricus bisporus, respectively). Iron content was between 16.4 and $39 \mathrm{mg} / 100 \mathrm{~g}$ on dry weight base for Agaricus bisporus and Pleurotus ostreatus, respectively. Zinc content was between 


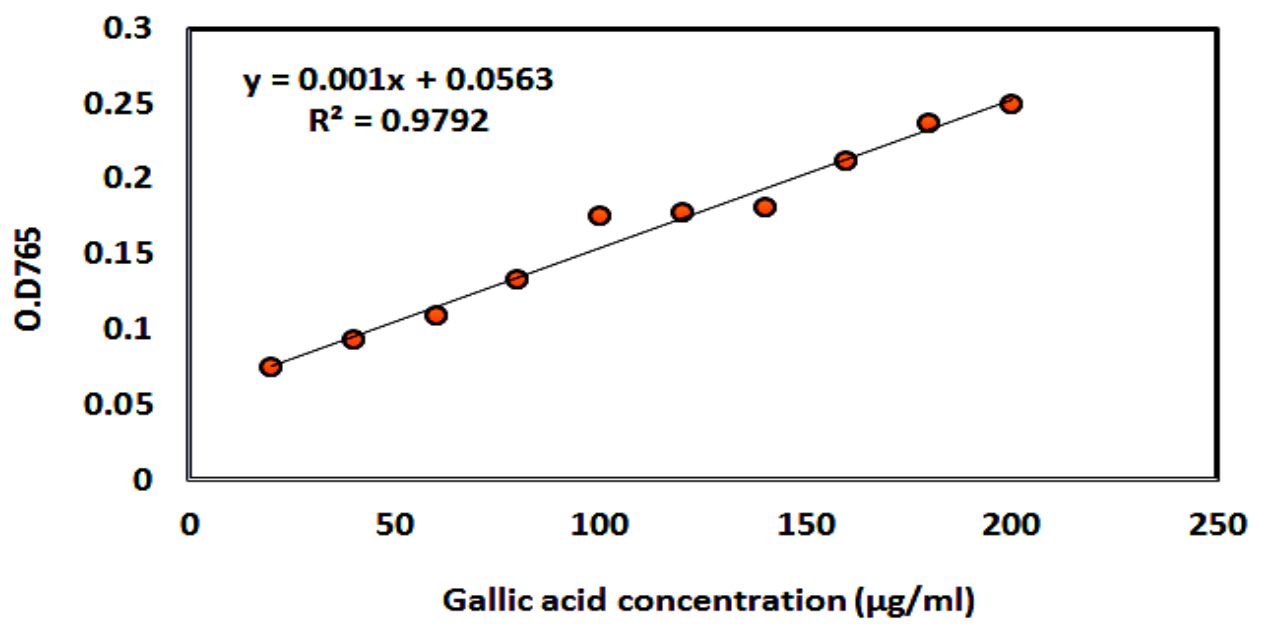

Fig. 1. Standard curve for gallic acid

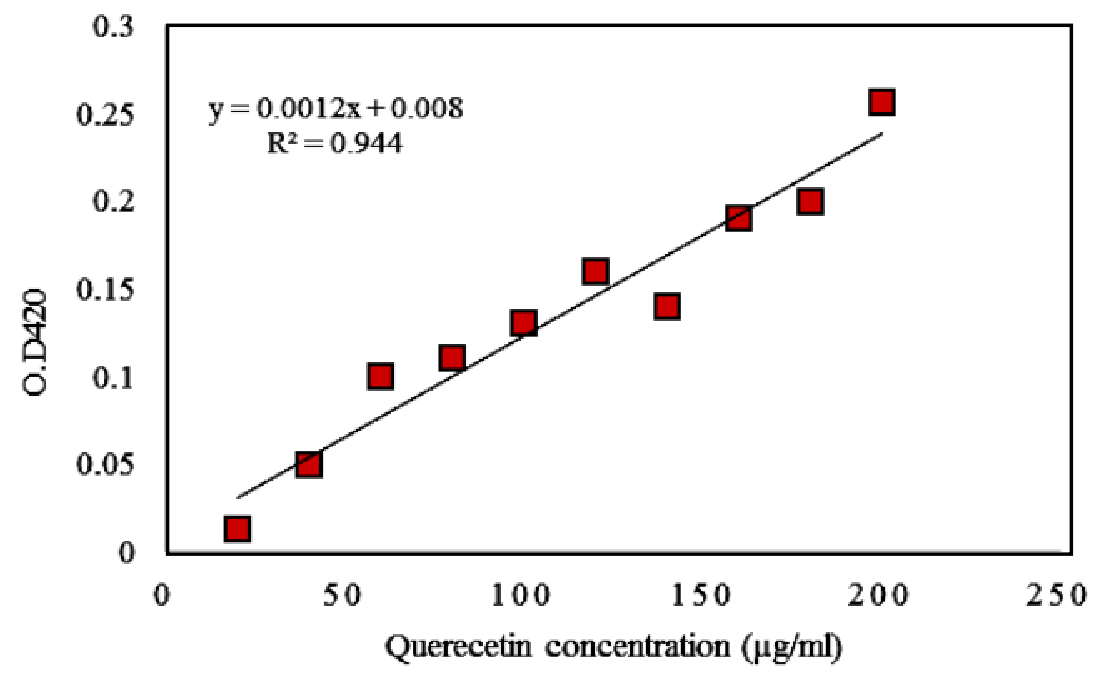

Fig. 2. Standard curve for quercetin

Table 1. Proximate composition of Pleurotus ostreatus and Agaricus bisporus mushroom species

\begin{tabular}{lcc}
\hline Parameter & \multicolumn{2}{c}{ Concentration $^{\mathbf{a}}(\mathbf{g} / \mathbf{1 0 0} \mathbf{g}$ fresh weight $)$} \\
\cline { 2 - 3 } & Pleurotus ostreatus & Agaricus bisporus \\
\hline Moisture & $90.47 \pm 0.88$ & $90.55 \pm 0.65$ \\
Ash & $0.65 \pm 0.002$ & $0.43 \pm 0.004$ \\
Crude fat & $0.28 \pm 0.003$ & $0.22 \pm 0.002$ \\
Crude protein & $3.25 \pm 0.02$ & $3.48 \pm 0.01$ \\
Total carbohydrates & $5.35 \pm 0.03$ & $5.23 \pm 0.02$ \\
\hline
\end{tabular}

${ }^{\mathrm{a}}$ Values are mean \pm standard deviation of triplicate determinations. 
Zagazig J. Agric. Res., Vol. 45 No. (4) 2018

Table 2. Mineral composition of flour from Pleurotus ostreatus and Agaricus bisporus mushroom species

\begin{tabular}{lcc}
\hline Mineral & \multicolumn{2}{c}{ Concentration $(\mathbf{m g}$ / 100 g dry matter) } \\
\cline { 2 - 3 } & Pleurotus ostreatus & Agaricus bisporus \\
\hline Iron & 39 & 16.4 \\
Zinc & 3.5 & 6.1 \\
Potassium & 2820.5 & 2376.8 \\
Sodium & 65.73 & 75.3 \\
Calcium & 29.93 & 42.1 \\
Manganese & 3.1 & 4.4 \\
Copper & 4.8 & 7.6 \\
Magnesium & 173.43 & 120 \\
Phosphorus & 537 & 754 \\
\hline
\end{tabular}

3.5 and $6.1 \mathrm{mg} / 100 \mathrm{~g}$ on dry weight base for Pleurotus ostreatus and Agaricus bisporus, respectively. Sodium content was between 65.73 and $75.3 \mathrm{mg} / 100 \mathrm{~g}$ on dry weight base for Pleurotus ostreatus and Agaricus bisporus, respectively. Calcium content was between 29.93 and $42.1 \mathrm{mg} / 100 \mathrm{~g}$ on dry weight base for Pleurotus ostreatus and Agaricus bisporus, respectively. Magnesium content was between 120 and $173.43 \mathrm{mg} / 100 \mathrm{~g}$ on dry weight base for Agaricus bisporus and Pleurotus ostreatus, respectively. Copper content was between 4.8 and $7.6 \mathrm{mg} / 100 \mathrm{~g}$ on dry weight base for Pleurotus ostreatus and Agaricus bisporus, respectively. Manganese levels are not so high in mushrooms (ranging from 3.1 to $4.4 \mathrm{mg} / 100$ $\mathrm{g}$ on dry weight base for Pleurotus ostreatus and Agaricus bisporus, respectively).

\section{Total Phenolic Contents (TPC)}

The TPC values are presented in Fig. 3. The results obtained for Pleurotus ostreatus mushroom in Folin Ciocalteu assay were 23, 55, 56 and 46 mg GAE/g for ethyl acetate, ethanol, methanol and aqueous extracts, respectively. Likewise, Agaricus bisporus mushroom recorded in Folin Ciocalteu assay were 36, 77, 164, and $119 \mathrm{mg}$ $\mathrm{GAE} / \mathrm{g}$ for ethyl acetate, ethanol, methanol and aqueous extracts, respectively. The results obtained in these investigation were higher than results obtained by (Yang $\boldsymbol{e t}$ al., 2002; Oke and Aslim, 2011; Reis et al., 2012).

\section{Total Flavonoid Contents (TFCs)}

The TFC values are presented in Fig. 4. The results obtained for Pleurotus ostreatus mushroom were $11,15.23$ and $16 \mathrm{mg} \mathrm{QE} / \mathrm{g}$ for ethyl acetate, ethanol, methanol, and water extracts, respectively. Likewise, Agaricus bisporus mushroom recorded 22, 45, 100 and $92 \mathrm{mg} \mathrm{QE/g}$ for ethyl acetate, ethanol, methanol, and water extracts, respectively.

\section{Antioxidants Activity (DPPH assay)}

The 2, 2-diphenyl-1-picrylhydrazyl (DPPH) radical is a long-lived organic nitrogen radical with a deep purple color. In the performed method, the purple chromogen radical is reduced by antioxidant/reducing compounds to the corresponding pale yellow hydrazine, according to the following equation:

$$
\mathrm{Z}^{\cdot}+\mathrm{AH}---------\mathrm{ZH}+\mathrm{A}^{*}
$$

Where $\mathrm{Z}^{\circ}$ represents the DPPH radical and the donor molecule is represented by $\mathrm{AH}$. In this reaction, $\mathrm{ZH}$ is the reduced form and $\mathrm{A}^{\circ}$ is the free radical produced in this first step. This latter radical will then undergo further reactions which control the overall stoichiometry, that is, the number of molecules of DPPH reduced (decolorised) by one molecule of the reductant (Molyneux, 2004). This reduction could be monitored measuring the absorbance decrease at $515-528 \mathrm{~nm}$ until the absorbance remains stable 


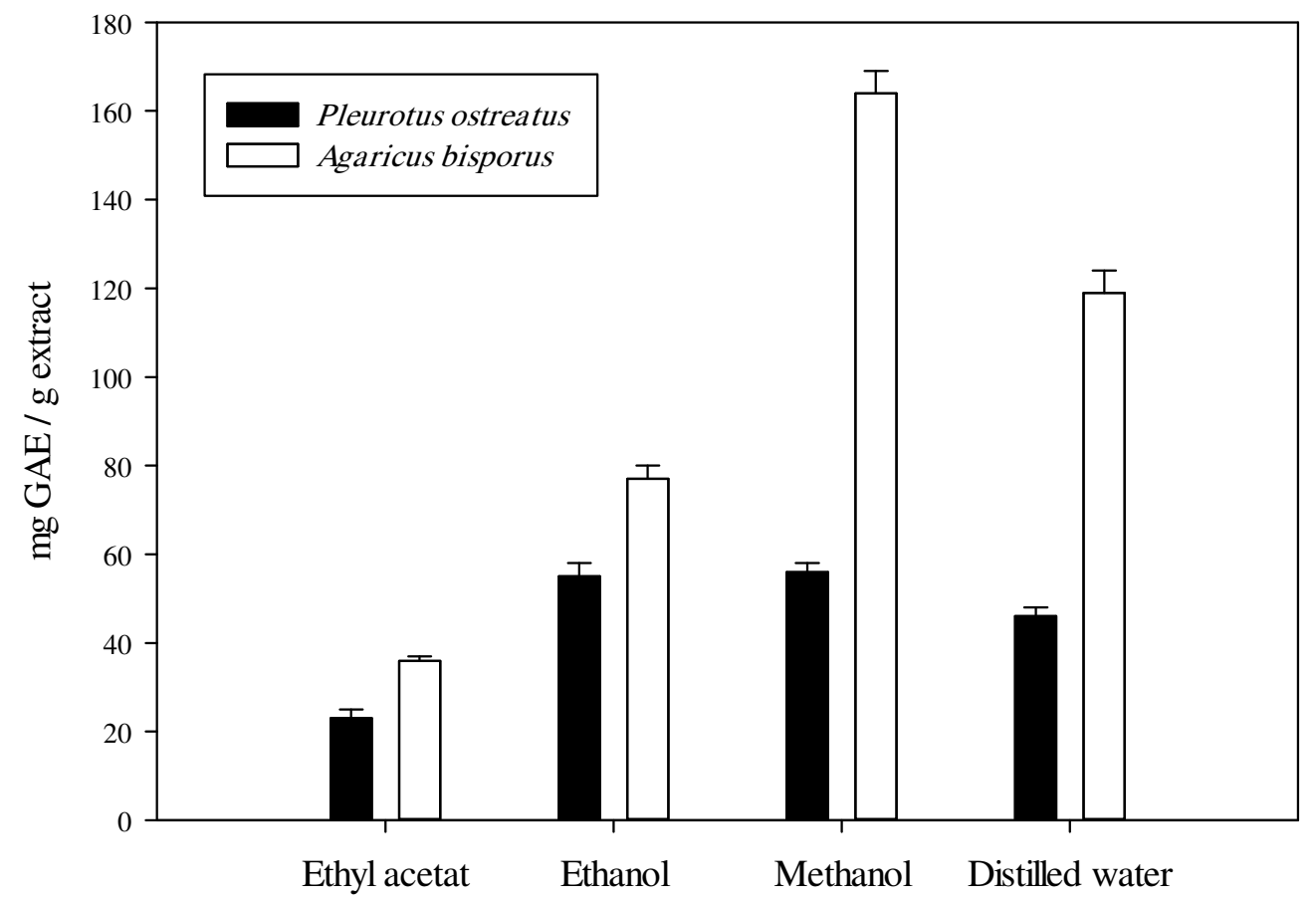

Fig. 3. Total phenolic contents (mg GAE/g extract) for different extracts from Pleurotus ostreatus and Agaricus bisporus mushroom species

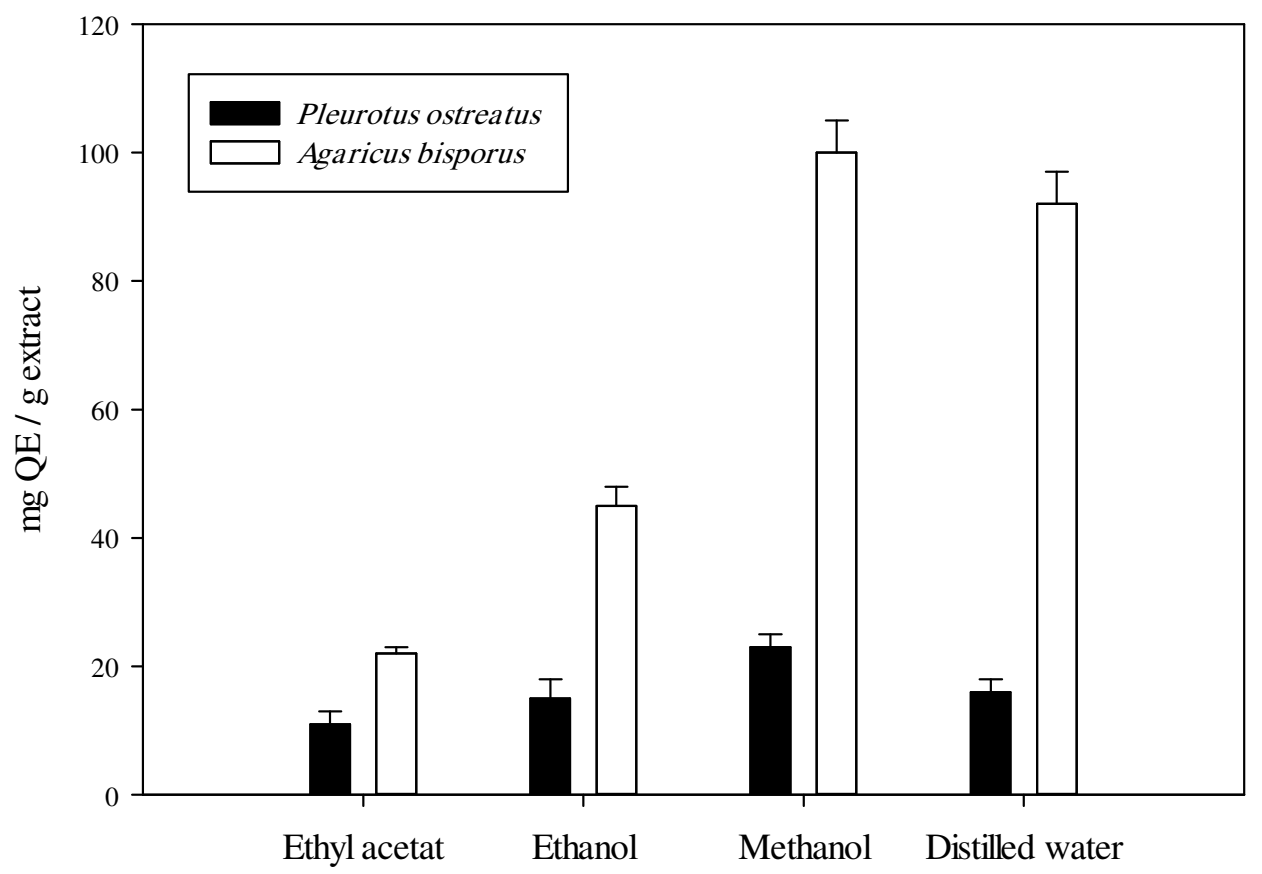

Fig. 4. Total flavonoid contents (mg QE/g extract) for different extracts from Pleurotus ostreatus and Agaricus bisporus mushroom species 


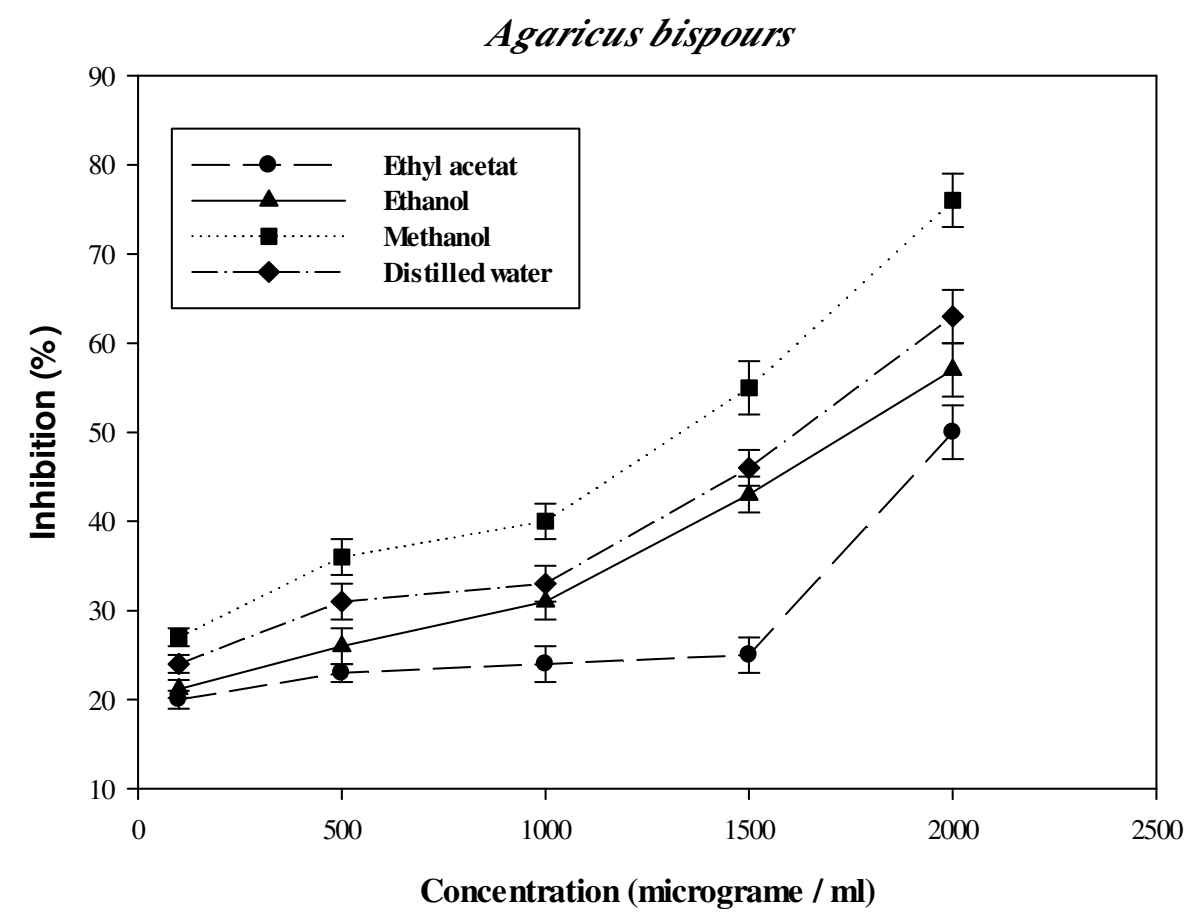

Fig. 5. Antioxidants activity (inhibition \%) for different extracts from Agaricus bisporus using DPPH assay

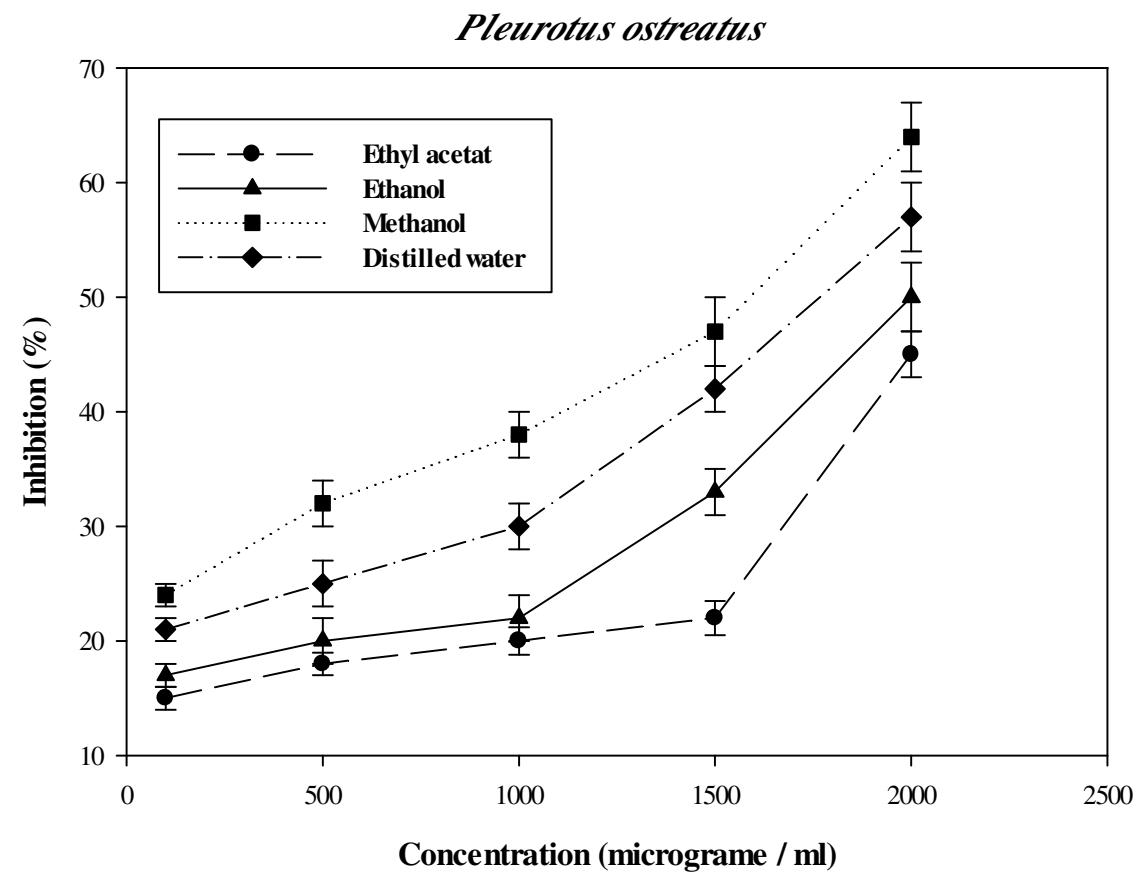

Fig. 6. Antioxidants activity (inhibition \%) for different extracts from Pleurotus ostreatus using DPPH assay 
in organic media (Karadag et al., 2009), and free radical scavenging activity can be determined by the discoloration of the DPPH solution (Ndhlala et al., 2010).

Antioxidants activity (\% inhibition) for different extracts from Agaricus bisporus or Pleurotus ostreatus using DPPH assay are presented in Figs. 5 and 6.

Agaricus bisporus was the specie that presented the highest radical scavenging activity compared with Pleurotus ostreatus. These results compatible with our results recorded in total phenolic compounds. It can be noted that, the antioxidant activity of different extracts in two mushrooms (Agaricus bisporus and Pleurotus ostreatus) increased gradually with increasing concentration of TPCs and TFCs. These results are in agreement with results obtained by (Chirinang and Intarapichet, 2009; Tsai et al., 2009; Oke and Aslim, 2011).

\section{Conclusions}

In conclusion, mushrooms, in spite of the great variability observed among species, represent an interesting food item that can contribute to the formulation of a well-balanced diet.

\section{REFERENCES}

Adejumo, T.O. and O.B. Awosanya (2005). Proximate and mineral composition of four edible mushroom species from South Western Nigeria. Afr. J. Biotechnol., 4 (10): 1084-1088.

Barros, L., P. Baptista, D.M. Correia, J. Sá Morais and I.C. Ferreira (2007). Effects of conservation treatment and cooking on the chemical composition and antioxidant activity of Portuguese wild edible mushrooms. J. Agric. and Food Chem., 55: 4781-4788.

Braaksma, A. and D. Schaap (1996). Protein analysis of the common mushroom Agaricus bisporus. Postharvest Biol. and Technol., 7: 119-127.

Chen, J.N., Y.T. Wang and J.S.B. Wu (2009). A glycoprotein extracted from golden oyster mushroom Pleurotus citrinopileatus exhibiting growth inhibitory effect against U937 leukemia cells. J. Agric. and Food Chem., 57: 6706-6711.

Chirinang, P. and K.O. Intarapichet (2009). Amino acids and antioxidant properties of the oyster mushrooms, Pleurotus ostreatus and Pleurotus sajor-caju. Sci. Asia, 35: 326331.

Chudzyński, K. and J. Falandysz (2008). Multivariate analysis of elements content of Larch Bolete (Suillus grevillei) mushroom. Chemosphere, 73: 1230-1239.

Dore, C.M.G., T.C. Azevedo, M.C. de Souza, L.A. Rego, J.C. de Dantas, F.R. Silva, H.A. Rocha, I.G. Baseia and E.L. Leite (2007). Anti inflammatory, antioxidant and cytotoxic actions of $\beta$-glucan-rich extract from Geastrum saccatum mushroom. Int. Immunopharmacol., 7: 1160-1169.

Dubois, M., K.A. Gilles, J.K. Hamilton, P.T. Rebers and F. Smith (1956). Colorimetric method for determination of sugars and related substances. Anal. Chem., 28:350-356.

Fernandes, Â., J.C. Barreira, A.L. Antonio, M.B.P. Oliveira, A. Martins and I.C. Ferreira (2014). Effects of gamma irradiation on chemical composition and antioxidant potential of processed samples of the wild mushroom Macrolepiota procera. Food Chem., 149: 91-98.

Garcia-Lafuentea, A., C. Moro, A. Villares, E. Guillamon, A.M. Rostagno, M. D'Arrigo, J.A. Martinez (2010). Mushrooms as a source of anti-inflammatory agents. AntiInflammatory and Anti-Allergy Agents in Med. Chem., Formerly Current Med. Chem.Anti-Inflammatory and Anti-Allergy Agents, 9: $125-141$.

Gülçin, I., Ö.İ. Küfrevioğlu, M. Oktay and M.E. Büyükokuroğlu (2004). Antioxidant, antimicrobial, antiulcer and analgesic activities of nettle (Urtica dioica L.). J. Ethnopharmacol., 90: 205-215.

Hatano, T., H. Kagawa, T. Yasuhara and T. Okuda (1988). Two new flavonoids and other constituents in licorice root: their relative astringency and radical scavenging effects. Chem. and Pharm. Bulletin, 36: 2090-2097. 
Horwitz, W. and G. Latimer (2000). Official Methods of Analysis of AOAC International, Gaithersburg MA, USA. Ass. Official Anal. Chemist.

Karadag, A., B. Ozcelik and S. Saner (2009). Review of methods to determine antioxidant capacities. Food Anal. Methods, 2: 41-60.

León-Guzmán, M.F., I. Silva and M.G. López (1997). Proximate chemical composition, free amino acid contents, and free fatty acid contents of some wild edible mushrooms from Querétaro, México. J. Agric. and Food Chem., 45: 4329-4332.

Lindequist, U., T.H. Niedermeyer and W.D. Jülich (2005). The pharmacological potential of mushrooms. Evidence-Based Comp. and Alter. Med., 2: 285-299.

Manzi, P., L. Gambelli, S. Marconi, V. Vivanti and L. Pizzoferrato (1999). Nutrients in edible mushrooms: an inter-species comparative study. Food Chem., 65: 477-482.

Manzi, P., S. Marconi, A. Aguzzi and L. Pizzoferrato (2004). Commercial mushrooms: nutritional quality and effect of cooking. Food Chem., 84: 201-206.

Molyneux, P. (2004). The use of the stable free radical diphenylpicrylhydrazyl (DPPH) for estimating antioxidant activity. Songklanakarin J. Sci. Technol., 26:211-219.

Ndhlala, A.R., M. Moyo and J. Van Staden (2010). Natural antioxidants: fascinating or mythical biomolecules? Molec., 15: 69056930.

Oke, F. and B. Aslim (2011). Protective effect of two edible mushrooms against oxidative cell damage and their phenolic composition. Food Chem., 128 : 613-619.

Okoro, I. and F. Achuba (2012). Proximate and mineral analysis of some wild edible mushrooms. Afr. J. Biotechnol., 11: 77207724.

Ordonez, A., J. Gomez and M. Vattuone (2006). Antioxidant activities of Sechium edule (Jacq.) Swartz extracts. Food Chem., 97: 452-458.
Öztürk, M., M.E. Duru, Ș. Kivrak, N. MercanDoğan, A. Türkoglu and M.A. Özler (2011). In vitro antioxidant, anticholinesterase and antimicrobial activity studies on three Agaricus species with fatty acid compositions and iron contents: A comparative study on the three most edible mushrooms. Food and Chem. Toxicol., 49: 1353-1360.

Puttaraju, N.G., S.U. Venkateshaiah, S.M. Dharmesh, S.M.N. Urs and R. Somasundaram (2006). Antioxidant activity of indigenous edible mushrooms. J. Agric. and Food Chem., 54: 9764-9772.

Reis, F.S., A. Martins, L. Barros and I.C. Ferreira (2012). Antioxidant properties and phenolic profile of the most widely appreciated cultivated mushrooms: a comparative study between in vivo and in vitro samples. Food and Chem. Toxicol., 50: 1201-1207.

Singleton, V.L., R. Orthofer and R.M. LamuelaRaventós (1999). Analysis of total phenols and other oxidation substrates and antioxidants by means of folin-ciocalteu reagent, Methods in enzymology, Elsevier, 152-178.

Smolskaite, L., P.R. Venskutonis and T. Talou (2015). Comprehensive evaluation of antioxidant and antimicrobial properties of different mushroom species. LWT-Food Sci. and Technol., 60: 462-471.

Tsai, S.Y., S.J. Huang, S.H. Lo, T.P. Wu, P.Y. Lian and J.L. Mau (2009). Flavour components and antioxidant properties of several cultivated mushrooms. Food Chem., 113: 578-584.

Wang, X.M., J. Zhang, L.H. Wu, Y.L. Zhao, T. Li, J.Q. Li, Y.Z. Wang and H.G. Liu (2014). A mini-review of chemical composition and nutritional value of edible wild-grown mushroom from China. Food Chem., 151: 279-285.

Yang, J.H., H.C. Lin and J.L. Mau (2002). Antioxidant properties of several commercial mushrooms. Food Chem., 77: 229-235. 
التركيب الكيميائى والنثاط المضاد للأكسدة لاثنين من فطر عيش الغراب الصالحة للغذاء

$$
\begin{aligned}
& \text { أمال صلاح على - على عثمان عثمان - رجب عبدالفتاح المصرى - سيد سليمان السعدنى }
\end{aligned}
$$

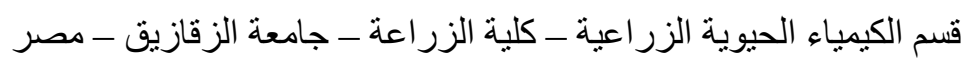

في هذا البحث تمت در اسة التركيب الأولى، ومحتوى المعادن لأثنين من فطر عيش الغر اب الصالحة للغذاء (بليوروتس الإنس

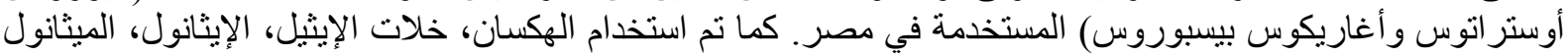

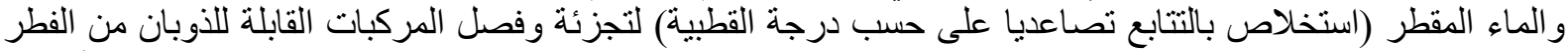

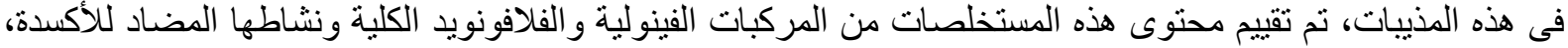

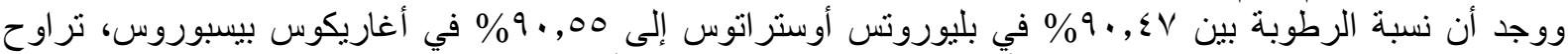

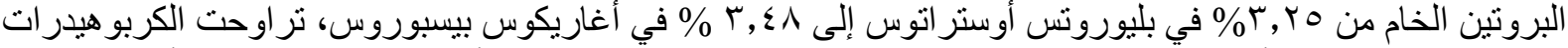

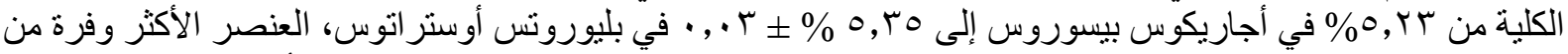

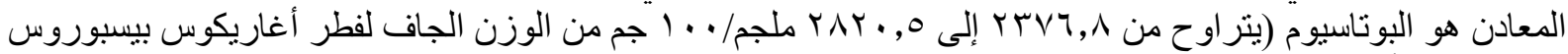

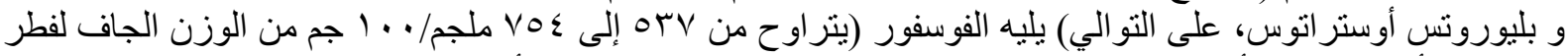

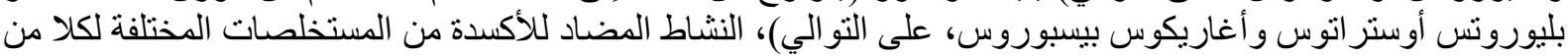

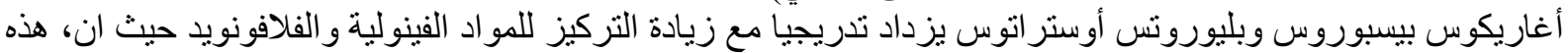

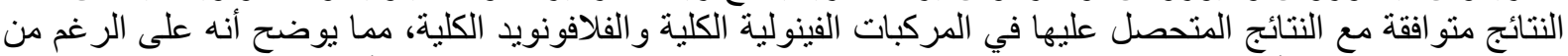

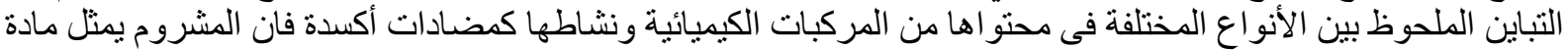
غذائية جيدة تساهم فى تكوين نظام غذائى متو ازن للانسان عموما ولذوى الأنسات الاحتياجات الخاصة.

أستاذ الكيمياء الحيوية ـ كلية الزراعة ـ جامعة القاهرة. أستاذ الكيمياء الحيوية المتفرغ ـ كلية الزر اعة ـ جامعة الزقازيقة الزية 